\title{
PERMASALAHAN DALAM MEWUJUDKAN KEMANDIRIAN INDUSTRI PERTAHANAN
}

\author{
Radhana Dwi Wibowo ${ }^{1}$
}

\begin{abstract}
Abstrak: Semenjak disahkan pada Tanggal 2 Oktober 2012, sudah tiga tahun Undang-Undang RI Nomor 16 Tahun 2012 menjadi payung hukum pelaksanaan kemandirian industri pertahanan. Berbagai alat peralatan pertahanan dan keamanan sudah dapat dipenuhi oleh industri pertahanan dalam negeri seperti panser Anoa 6x6, senapan serbu, pesawat patrol maritim CN-235 MPA dan beberapa kapal cepat rudal. Berbagai alat peralatan pertahanan dan keamanan ini dibutuhkan untuk mengejar target kekuatan pokok minimum (minimum essential force) yang telah disusun. Idealnya semua kebutuhan alat peralatan pertahanan dan keamanan dapat dipenuhi oleh industri pertahanan dalam negeri, namun ternyata hal tersebut belum bisa terwujud disebabkan beberapa faktor permasalahan, diantaranya permasalahan dari implementasi konsep tiga pilar pelaku industri pertahanan, permasalahan dari implementasi konsep kluster industri pertahanan dan permasalahan imbal dagang, kandungan lokal dan offset atas pengadaan alat peralatan pertahanan dan keamanan dari luar negeri.
\end{abstract}

Kata Kunci: industri pertahanan, kemandirian industri pertahanan

\section{PENDAHULUAN}

Industri pertahanan adalah industri nasional, baik milik pemerintah maupun swasta yang produknya baik secara mandiri maupun kelompok, termasuk jasa perawatannya dapat dimanfaatkan untuk kepentingan pertahanan Negara. Industri pertahanan merupakan jawaban dari tantangan keperluan pencapaian Minimum Essential Force (MEF) di lingkungan TNI dan sekaligus sebagai jawaban atas pengalaman pahit atas embargo militer pada dekade 90-an. Suatu Negara yang memiliki industri pertahanan dianggap mempunyai keuntungan strategis dalam tatanan global dikarenakan dianggap mampu melakukan penangkalan dan menjawab tantangan atau ancaman yang senantiasa berubah.

Upaya perwujudan kemandirian industri pertahanan tidak terlepas dari konsep tiga pilar pelaku industri pertahanan dan konsep kluster industri pertahanan. Konsep tiga pilar pelaku industri pertahanan mengacu pada hubungan yang terpadu antara Perguruan Tinggi dan komunitas Penelitian dan Pengembangan (Litbang) sebagai pengembang IImu Pengetahuan dan Teknologi (Iptek) pertahanan, sektor industri/swasta sebagai pendaya guna hasil Iptek pertahanan, produksi maupun distribusinya, serta TNI sebagai pengguna.

\footnotetext{
${ }^{1}$ Penulis bekerja di Bidang Lalu-Lintas Dinas Perhubungan Kota Surabaya, email: radhana_dwiwibowo@yahoo.com
}

Sedangkan konsep kluster Industri pertahanan artinya adalah adanya saling keterkaitan dan saling mendukung antara industri hulu, industri hilir, industri pendukung dan industri terkait untuk menciptakan daya saing dan meningkatkan industri nasional. Dari sisi regulasi, perwujudan kemandirian industri pertahanan juga di back-up oleh UndangUndang Republik Indonesia nomor 16 Tahun 2012 tentang Industri Pertahanan (Idhan) yang didalamnya terdapat kewajiban menggunakan Alat Utama Sistem Senjata (Alutsista) produksi dalam negeri. Di dalam UU Inhan tersebut juga didorong upaya alih teknologi, ataupun pendanaan dalam bentuk offset dan juga imbal dagang untuk produk alat peralatan pertahanan dan keamanan yang didatangkan dari luar negeri disebabkan industri pertahanan dalam negeri belum mampu membuatnya. Selain UU Inhan, perwujudan kemandirian industri pertahanan juga diatur dalam Peraturan Pemerintah Republik Indonesia nomor 74 Tahun 2014 tentang Mekanisme Imbal Dagang dalam Pengadaan Alat Peralatan Pertahanan dan Keamanan dari Luar Negeri.

Keberhasilan upaya perwujudan kemandirian industri pertahanan sangat bergantung kepada sinergi 3 pilar pelaku industri pertahanan dan berjalannya konsep kluster di atas pada sektor-sektor industri yang saling mendukung. Untuk 
mengetahui sejauh mana kedua konsep berjalan dengan baik, maka perlu dilakukan penelusuran mengenai permasalahanpermasalahan yang terjadi dan tantangan ke depan dalam upaya mewujudkan kemandirian industri pertahanan.

\section{PERMASALAHAN MEWUJUDKAN KEMANDIRIAN PERTAHANAN INDUSTRI}

Pada bagian ini akan dilakukan pembahasan mengenai permasalahan yang timbul dalam mewujudkan kemandirian industri pertahanan.

2.1 Permasalahan dari Implementasi Konsep Tiga Pilar Pelaku Industri Pertahanan

Di antara para pelaku industri pertahanan, seperti badan-badan Litbang ataupun perguruan tinggi, pelaku industri dan pengguna, harus terjadi sinergi. Sinergi ini bisa terwujud jika ada kesesuaian antara roadmap pengembangan alat peralatan pertahanan dan keamanan dan implementasi di lapangan. Jika tidak demikian maka akan menghambat proses kemandirian industri pertahanan itu sendiri. Dari sisi Litbang misalnya, sudah banyak prototipe alat peralatan pertahanan dan keamanan yang dihasilkan, namun belum tentu dilirik oleh TNI sebagai pengguna. Permasalahan produk Litbang ini terkait erat dengan roadmap pengembangan alat peralatan pertahanan dan keamanan yang akan dibuat. Prototipe yang dibuat harus sudah sesuai dengan standar spesifikasi dan kebutuhan operasional TNI sebagai pengguna. Pada akhirnya prototipe tersebut perlu terus disempurnakan agar bisa sesuai dengan spesifikasi yang dibutuhkan TNI. Sebagai contoh dapat kita ambil proses penelitian dan pengembangan senapan serbu oleh Litbang PT. Pindad. Proses pengembangan senapan serbu diawali dari retrofit senapan FNC, ex FN Belgia pada Tahun 1983 yang kemudian dilakukan lisensi pada Tahun 1984. Setelah 7 tahun berjalan hingga Tahun 1990 dan setelah dilakukan penyempurnaan pada 7 komponen, maka dihasilkan SS1-V2 jenis karabin. Proses ini berlanjut terus hingga antara Tahun 1990-2000, dengan dihasilkannya SS1-V3, SS1-R5 untuk
Raider dan SS1-M1 untuk Marinir. Kemudian antara Tahun 2000-2010 berkembang lagi menjadi SS2-V1, SS2-V2 tipe karabin, SS2-V4 yang dilengkapi tele KISS dan SS2-V5 tipe komando untuk pasukan khusus. Demikian sekelumit cerita penelitian dan pengembangan senapan serbu oleh PT. Pindad seperti yang ditunjukkan oleh Gambar 1 di bawah ini. Proses penelitian dan pengembangan terus dilakukan hingga didapatkan produk yang sesuai dengan spesifikasi yang diinginkan TNI dan mendukung kebutuhan operasi mereka.

Permasalahan berikutnya dalam implementasi konsep ini, adalah permasalahan yang disebabkan oleh pengguna. Permasalahan dari sisi pengguna contohnya adalah kontinuitas pemesanan alat peralatan pertahanan dan keamanan. Contoh permasalahan kontinuitas ini terjadi pada pemesanan panser Anoa 6x6 kepada PT Pindad. Pada Tahun 2008, sebanyak 150 unit Anoa 6x6 dipesan langsung oleh Wapres Jusuf Kalla saat itu untuk memenuhi kebutuhan TNIAD. Jumlah total dana yang dikucurkan pemerintah saat itu untuk membeli 150 unit Anoa 6x6 melebihi Rp 1 trilliun sehingga operasional produksi Anoa 6x6 waktu itu pun berjalan lancar. Namun pada Tahun 2011 yang dipesan hanya 11 unit Anoa 6x6, Tahun 201261 unit Anoa 6x6, serta pada Tahun 2013 PT Pindad mendapatkan pesanan 82 unit Anoa 6x6.

Walaupun jika dijumlahkan, total produksi ranpur Anoa 6x6 mencapai 304 unit, namun kita bisa melihat adanya ketidakkontinuitas pemesanan oleh Kementerian Pertahanan. Hal ini disebabkan alokasi anggaran untuk pemesanan ranpur Anoa 6x6 tersebut tidak tetap setiap tahun. Akibatnya jika diratarata mulai Tahun 2008 hingga Tahun 2014, produksi Anoa $6 \times 6$ rata-rata 50-an unit/tahun, masih di bawah angka kemampuan lini produksi PT. Pindad. Padahal, PT Pindad sendiri kemampuan lini produksinya sudah mampu memproduksi 80 unit Anoa per tahun.

Bentuk permasalahan lain adalah ketidaksiapan industri dalam negeri untuk menyokong kemandirian industri pertahanan. Ketidaksiapan ini bisa disebabkan karena belum adanya 
infrastruktur pendukung maupun dukungan dana untuk melakukan produksi alat peralatan pertahanan dan keamanan secara masal.

Dan permasalahan yang terakhir dari implementasi konsep ini adalah dari sektor industri. Jika dikaitkan dengan roadmap pengembangan alat peralatan pertahanan dan keamanan, apakah sanggup untuk memberikan jaminan bahwa produk yang akan dihasilkan sesuai dengan spesifikasi yang diinginkan TNI dari segi kualitas. Apabila kualitas produk yang dihasilkan tidak sesuai dengan spesifikasi yang dibutuhkan TNI, maka kebutuhan operasi TNI akan terganggu, dan beresiko bagi personel di lapangan. Misalnya saja kualitas bahan yang digunakan untuk memproduksi senapan serbu kurang bagus, hal ini akan bisa mengakibatkan senapan serbu macet, cepat panas dan akurasi yang buruk. Akibatnya upaya peningkatan kemampuan SDM TNI terganggu. Akibat lebih buruknya jika negara dalam kondisi berperang tentu akan menghambat kesiapan personel.

Selain itu, ketepatan waktu produksi juga sangat penting. Keterlambatan pengerjaan produk membawa dampak negatif bagi rencana-rencana strategis TNI dan kesiapan operasional.

\subsection{Permasalahan dari Implementasi Konsep Kluster Industri Pertahanan}

Inti dari implementasi konsep kluster industri pertahanan adalah terciptanya saling keterkaitan dan saling mendukung antara industri hulu dan industri hilir. Industri hulu berkaitan erat dengan pengolahan bahan baku menjadi barang setengah jadi. Sedangkan industri hilir adalah industri yang mengolah barang setengah jadi tersebut menjadi barang jadi. Di Indonesia bentuk industri hulu yang berkaitan dengan industri pertahanan adalah industri pengolahan baja oleh PT. Krakatau Steel. Baja-baja ini dibutuhkan oleh PT. Pindad di dalam pembuatan kendaraan tempur TNI semisal Anoa 6x6.

Di dalam perwujudan kemandirian industri pertahanan, industri hulu maupun industri hilir di dalam negeri harus mampu mendukung kebutuhan pasokan alat peralatan pertahanan dan keamanan bagi TNI. Keterkaitan yang erat antara industri hulu dan industri hilir di dalam negeri akan mendorong semakin besar kandungan lokal di dalam alat peralatan pertahanan dan keamanan yang dihasilkan. Semakin banyak komponen mampu dibuat di dalam negeri, maka kandungan lokalnya juga semakin besar.

Di Indonesia saat ini untuk kebutuhan kendaraan tempur berupa panser, keberadaan PT Pindad sudah cukup. Apalagi kemampuan PT. Pindad juga lumayan besar, mampu untuk menghasilkan 80 unit panser per tahun. Namun jika yang ingin dikejar adalah semua alat peralatan pertahanan dan keamanan mampu diproduksi di dalam negeri, hal ini masih sangat jauh karena industri pertahanan kita saat ini belum mampu membuat sendiri tank tempur utama (main battle tank), meriam swagerak (self-propelled howitzer), pesawat tempur, kapal selam, dan lain sebagainya. $\mathrm{Hal}$ ini dikarenakan industri dalam negeri kita baik industri hulu maupun industri hilir belum mampu memproduksi komponenkomponen yang dibutuhkan semisal teknologi armour, meriam untuk tank, turret, mesin pesawat tempur, avionik, combat management system (CMS), dan lain sebagainya.

\subsection{Permasalahan Imbal Dagang, Kandungan Lokal dan Offset untuk Pengadaan dari Luar Negeri}

Menurut Peraturan Pemerintah No. 76 Tahun 2014 tentang Mekanisme Imbal Dagang dalam Pengadaan Alat Peralatan Pertahanan dan Keamanan dari Luar Negeri Pasal 1, imbal dagang didefinisikan sebagai kegiatan perdagangan secara timbal balik antara Indonesia dengan pihak luar negeri yang diukur dalam nilai transaksi kontrak pengadaan alat peralatan pertahanan dan keamanan. Imbal dagang merupakan salah satu bentuk mekanisme pengadaan alat peralatan pertahanan keamanan dari luar negeri selain kandungan lokal dan offset. Bentuk pengadaan dari luar negeri tidak melulu pembelian alat peralatan pertahanan dan keamanan, namun juga berbentuk perbaikan dan pemeliharaan dikarenakan di dalam negeri belum mampu melakukan perbaikan dan pemeliharaan sendiri. Imbal dagang dalam pengadaan alat peralatan 
pertahanan dan keamanan dari luar negeri dilakukan melalui barter atau imbal beli. Komponen yang dapat dilakukan mekanisme imbal dagang diantaranya barang dan/atau jasa Industri Pertahanan, barang industri manufaktur, maupun produk lain yang menguntungkan perekonomian nasional. Berikutnya yang dimaksud dengan kandungan lokal adalah semua produk dalam negeri yang dimiliki oleh orang perseorangan atau badan hukum Indonesia. Komponen yang dapat dilakukan mekanisme kandungan lokal meliputi rancang bangun, perekayasaan, hak atas kekayaan intelektual, bahan baku, biaya sarana dan prasarana, pendidikan dan pelatihan, biaya tenaga kerja maupun pelayanan purna jual.

Terakhir, yang dimaksud dengan offset adalah pengaturan antara Pemerintah dan pemasok senjata dari luar negeri untuk mengembalikan sebagian nilai kontrak kepada negara pembeli sebagai salah satu persyaratan jual beli. Offset diberikan dalam bentuk kegiatan yang berkaitan langsung maupun kegiatan yang tidak berkaitan langsung dengan alat peralatan pertahanan dan keamanan yang dibeli. Komponen offset meliputi perawatan dan pemeliharaan, overhaul, refurbishment dan modifikasi, retrofit dan upgrade, produksi berdasarkan lisensi, saham patungan, beli kembali, produksi bersama, subkontrak, pengembangan kompetensi pada penelitian dan pengembangan, pengembangan bersama, alih teknologi, alih kompetensi melalui penelitian dan pendidikan, pengembangan pemasaran produk industri pertahanan, maupun investasi untuk industri manufaktur dimana offset ini tidak dapat diganti dengan pembayaran tunai.

Jika merunut Peraturan Pemerintah di atas, besaran kewajiban pelaksanaan imbal dagang, kandungan lokal dan/atau offset idealnya paling rendah $85 \%$ dari nilai kontrak. Sedangkan besaran kewajiban pelaksanaan kandungan lokal dan/atau offset idealnya paling rendah $35 \%$ dari nilai kontrak dengan peningkatan $10 \%$ setiap 5 tahun. Sebagai contoh bentuk kandungan lokal adalah penggunaan Truk Hino sebagai platform kendaraan pengangkut Sistem Pertahanan Udara Skyshield yang dioperasikan TNI AU.

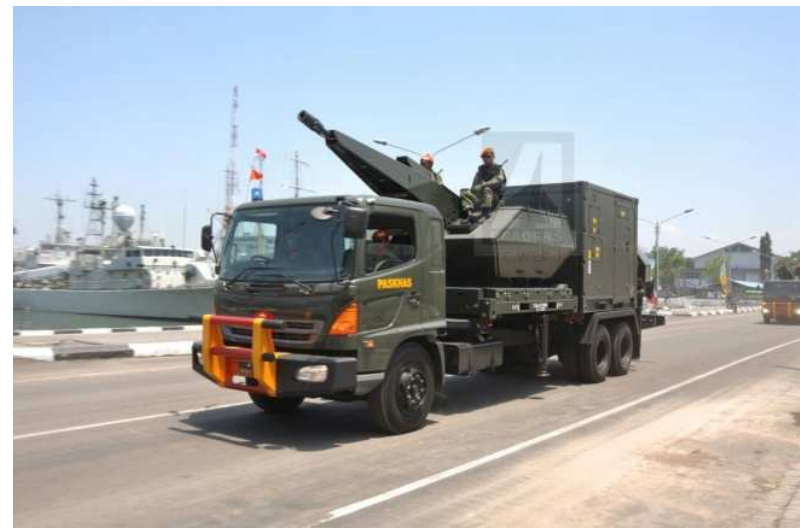

Gambar 2. Sistem Pertahanan Udara Skyshield dengan Platform Kendaraan Pengangkut Truk Hino pada Persiapan HUT TNI 5 Oktober 2014 (Angkasa Reader Community)

\section{UPAYA PEMECAHAN MASALAH}

Dari permasalahan-permasalahan di atas, ada beberapa pemecahan masalah yang perlu dilaksanakan dan sedang dilaksanakan, di antaranya:

\subsection{Pemecahan Masalah Implementasi Konsep Tiga Pilar Pelaku Industri Pertahanan}

Permasalahan implementasi konsep ini dapat diwujudkan dengan adanya roadmap yang jelas pengembangan alat peralatan pertahanan dan keamanan tahapan demi tahapan. Penyusunan roadmap ini harus dirumuskan bersamasama di antara ketiga pilar pelaku di atas. Sebagai contoh dapat kita lihat dari roadmap penelitian dan pengembangan yang dilakukan oleh PT. Pindad dalam gambar 3 di bawah ini.

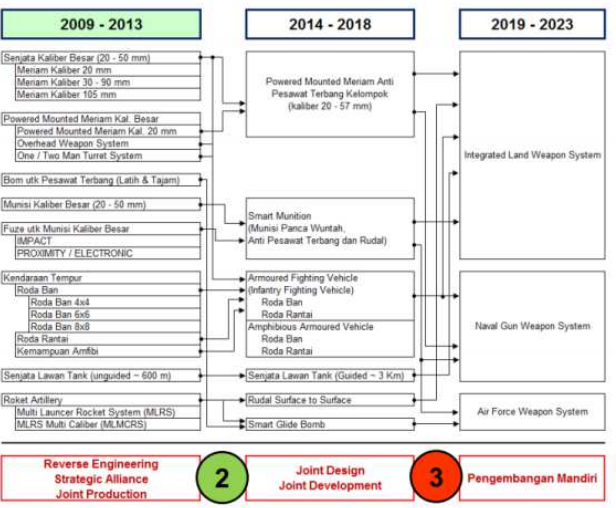

Gambar 3. Roadmap Pengembangan alat peralatan pertahanan dan keamanan oleh PT. Pindad (Paparan Dirut PT Pindad pada Peringatan Harteknas 2011)

Dari sisi pengguna, mereka bisa menentukan spesifikasi detail yang dibutuhkan untuk keperluan operasi seperti 
apa. Selanjutnya proses penelitian dan pengembangan alat peralatan pertahanan dan keamanan yang diinginkan dapat dilakukan oleh badan-badan Litbang yang ada. Proses penelitian dan pengembangan prototipe tidak harus dimulai dari nol. Prototipe alat peralatan pertahanan dan keamanan yang akan dikembangkan bisa merupakan hasil lisensi produk suatu negara sehingga dapat memangkas waktu penelitian dan pengembangan bila dibandingkan dengan dimulai dari nol.

Detail spesifikasi prototipe alat peralatan pertahanan dan keamanan yang akan diteliti dan dikembangkan harus benar-benar dipahami oleh badan-badan Litbang agar penelitian dan pengembangan tidak berujung sia-sia dan berakhir di prototipe saja. Detail spesifikasi ini juga harus dipahami oleh pihak industri selaku pendaya guna hasil penelitian dan pengembangan tersebut karena alat peralatan pertahanan dan keamanan tersebut berkaitan dengan kebutuhan operasional TNI. Standar kualitas produksi harus benar-benar dipantau terus agar produk yang dihasilkan benar-benar sesuai standar yang diharapkan TNI.

Jika hasil penelitian dan pengembangan sudah sesuai standar yang diinginkan TNI, begitu pula standar kualitas hasil produksipun demikian, maka selanjutnya dibutuhkan komitmen TNI di dalam menggunakan alat peralatan pertahanan dan keamanan yang dimaksud. Komitmen itu berbentuk kontinuitas pemesanan kepada pihak industri. Hal ini penting sekali agar proses kemandirian industri pertahanan terus dapat berjalan.

\subsection{Pemecahan Masalah Implementasi Konsep Kluster Industri Pertahanan}

Permasalahan implementasi konsep kluster industri dapat diatasi bila ada keseriusan dari pemerintah untuk melakukan pembenahan maupun penambahan infrastruktur pendukung industri pertahanan, baik industri hulu maupun industri hilir. Hal ini penting sekali karena pembenahan maupun penambahan infrastruktur baru akan menambah kemampuan memproduksi komponenkomponen lokal yang dibutuhkan untuk mendukung produksi alat peralatan pertahanan dan keamanan yang dibutuhkan. Semakin banyak komponen lokal yang mampu dibuat di dalam negeri, maka semakin besar kandungan lokal dalam suatu alat peralatan pertahanan dan keamanan yang dibuat. Hal ini juga memiliki dampak positif semakin berkurangnya ketergantungan pengadaan komponen dari luar negeri, semisal kebutuhan suku cadang maupun amunisi. Sebagai contoh, untuk mewujudkan keinginan mampu membuat kapal selam hasil kerja sama dengan Korea Selatan, pemerintah menggelontorkan dana Rp 1,5 triliun untuk membangun infrastruktur pembangunan kapal selam di PT. PAL Indonesia. Dana $\mathrm{Rp} \quad 1,5$ triliun ini merupakan dana tahap awal yang digelontorkan pemerintah dari total kebutuhan $\mathrm{Rp} 2,5$ triliun untuk pembangunan infrastruktur kapal selam, sesuai dengan Surat Menteri BUMN nomor S-396/MBU/2014 tanggal 7 Juli 2014. Kekurangan $\mathrm{Rp} 1$ triliun lagi akan diusulkan dalam RAPBN tahun berikutnya lagi.

\subsection{Pemecahan Masalah Imbal Dagang, Kandungan Lokal dan Offset}

Permasalahan imbal dagang, kandungan lokal dan offset terkait erat dengan pengadaan alat peralatan pertahanan dan keamanan dari luar negeri. Contoh nyata yang mencakup ketiganya adalah kerja sama antara Pemerintah Indonesia dengan Korea Selatan dalam joint development pesawat tempur KFX/IFX. Imbal dagangnya adalah berdatangannya alat peralatan pertahanan dan keamanan dari Negeri Ginseng tersebut masuk ke Indonesia, semisal LVT7 eks US Marine Corps, howitzer $\mathrm{KH}-178$, panser kanon Tarantula dan pesawat F/A50. Dari pendanaan program joint development pesawat KFX/IFX tersebut, Indonesia memiliki kontribusi pembiayaan 20:80 berbanding pembiayaan yang dilakukan Korea Selatan. Di dalam Scope of Cooperation, pihak Indonesia akan mendapatkan 1 unit prototipe pesawat dari 6 unit prototipe pesawat yang dibuat. 1 unit prototipe tersebut akan diserahkan Korea Selatan kepada Indonesia setelah seluruh uji terbang dilaksanakan (pesawat pertama sampai dengan keenam) dengan catatan para teknisi dan pilot uji dari Indonesia akan terlibat secara aktif dalam proses 
produksi prototipe dan prosesuji terbang seluruh prototipe tersebut. Setelah itu, prototipe akan diserahkan ke Indonesia untuk dilakukan final assembly, test and evaluation kembali.

Selain itu, dari hasil perundingan kedua negara, akan diproduksi 120 unit pesawat tempur KFX/IFX ini dengan Indonesia akan mendapat sekitar 50-an pesawat. Pesawat-pesawat ini akan dibangun di Indonesia mengingat sesuai kesepakatan, selain melakukan final assembly sendiri, Indonesia juga membangun lini produksi dengan biaya sendiri. Tentunya semua program dalam joint development pesawat KFX/IFX ini merupakan lompatan yang besar bagi upaya perwujudan kemandirian industri pertahanan dalam negeri di bidang pesawat tempur. Kita berharap lompatan besar untuk alat peralatan pertahanan dan keamanan yang lain sehingga pengadaanpengadaan dari luar negeri bisa kita minimalisir.

\section{PENUTUP}

Dari pembahasan di atas, dapat disimpulkan bahwa permasalahanpermasalahan yang muncul seputar upaya perwujudan kemandirian industri pertahanan dapat diatasi roadmap yang jelas, komitmen dan sinergi di antara para pelaku industri pertahanan. Hal tersebut juga perlu didukung oleh dukungan pembangunan infrastruktur-infrastruktur baru yang dapat menunjang sinergi hubungan antara industri hulu dan industri hilir di dalam memenuhi kebutuhan inudstri pertahanan dalam negeri. Selain itu diperlukan juga keberanian pemerintah untuk mengimplementasikan imbal dagang, kandungan lokal maupun offset akibat adanya pengadaan alat peralatan pertahanan dan keamanan dari luar negeri, baik itu melalui alih teknologi, pengembangan bersama (joint development), produksi bersama, dan lain sebagainya.

\section{DAFTAR PUSTAKA}

Antaranews, 2014. Spesifikasi pesawat tempur KFX/IFX Indonesia bisa berbeda. [online] Available at:< http://www.antaranews.com/berita/462 688/spesifikasi-pesawat-tempur-kfxifx- indonesia-bisa-berbeda $>$ [Diakses

Tanggal 11 Desember 2014]

Badan Penelitian dan Pengembangan

Kementerian Pertahanan RI, 2011.

Sebuah Pemikiran Tentang

Pembangunan Industri Pertahanan

Dalam Kemandirian Pertahanan

Negara. [online] Available at: <http://balitbang.kemhan.go.id/?q=con

tent/sebuah-pemikiran-tentang-

pembangunan-industri-pertahanan-

dalam-kemandirian-pertahanan-

negara $>$ [Diakses Tanggal

November 2014]

Defence Media Center Kementerian Pertahanan, 2014. Proyek Pesawat Tempur KF-X/IF-X Dipastikan Berlanjut. [online] Available at:< http://dmc.kemhan.go.id/post-proyekpesawat-tempur--kfxifx--dipastikanberlanjut.html>[Diakses Tanggal 11 Desember 2014]

Kementerian Riset dan Teknologi Republik Indonesia, 2009. Pentingnya Kemandirian Industri Pertahanan. [online] Available at: $<$ http://www.ristek.go.id/?module=New s\%20News\&id $=3464>$ [Diakses

Tanggal 21 November 2014]

Peran Pindad dalam Kemandirian Industri Pertahanan, Paparan Dirut PT. Pindad (Persero) pada Peringatan Harteknas 2011. 2011. Serpong: PT. Pindad (Persero).

Peraturan Pemerintah RI Nomor 76 Tahun 2014 tentang Mekanisme Imbal Dagang dalam Pengadaan Alat Peralatan Pertahanan dan Keamanan dari Luar Negeri

Tribunnews, 2014. Bangun Kapal Selam PT PAL Dapat Suntikan Dana Rp 1,5 Triliun. [online] Available at:< http://www.tribunnews.com/bisnis/201 4/09/17/bangun-kapal-selam-pt-paldapat-suntikan-dana-rp-15triliun>[Diakses Tanggal 5 Desember 2014]

Undang-Undang RI Nomor 16 Tahun 2012 tentang Industri Pertahanan 